\title{
Kesenian Tari Sufi: Studi Nilai Budaya dan Potensinya Sebagai Sumber Pembelajaran Antropologi di MAN 1 Magetan
}

\author{
Ninik Wijayanti \\ MAN 1 Magetan, Jl. Raya Takeran, Nampon, Magetan, Indonesia \\ Email: wijayantininik6@gmail.com
}

\begin{abstract}
Abstrak
Pertunjukan Tari Sufi MAN 1 Magetan dapat digali sebagai sumber belajar Antropologi bagi siswa, siswa dapat memperilajari nilai-nilai budaya dalam pertunjukan tari Sufi MAN 1 Magetan. Penelitian ini dilakukan di MAN 1 Magetan dalam kurun waktu 6 bulan. Menggunakan pendekatan kualitatif, dengan informan sebagai berikut: penari Sufi, Kyai Budi, Pembina ekstrakurikuler tari Sufi, guru-guru Sosiologi/Antropologi. Informan ditentukan dengan tehnik Purposive Sampling. Teknik pengumpulan data menggunakan observasi, wawancara dan dokumentasi. Data yang diperoleh divaliditasi dengan tehnik triangulasi sumber dan triangulasi metode. Teknik analisis data dengan cara interaktif dan berlangsung secara terus menerus dengan tahapan mereduksi, penyajian data dan menyimpulkan semua informasi secara benar. Tari Sufi MAN 1 Magetan dijadikan kegiatan ekstrakurikuler dan diminati peserta didik maupun masyarakat. Tari ini mempunyai tata cara gerakan seperti yang diajarkan Kyai Budi, tokoh Sufi Indonesia yang mengenalkan tarian ini di wilayah Magetan termasuk MAN 1 Magetan. Dalam penyajian bersifat luwes, kostum tidak memakai jubah hitam, yang dilepas waktu akan menari, warna kostum tidak harus hitam dan putih putih dan bisa bercorak, batik pring sedapur misalnya. Juga tidak memakai quff sebagai alas kaki tetapi memakai kaos kaki biasa. Pola lantai tidak mengikuti pola tertentu tetapi menyesuaikan dengan tempat pertunjukan dan jumlah penarinya. Tari Sufi MAN 1 Magetan mengandung nilai-nilai budaya, yaitu: nilai filosofi, nilai estetika, nilai spiritual, nilai perbaikan mental, nilai cinta kasih, nilai persaudaran, nilai silaturahmi, nilai sehat, dan nilai ekonomis. Tari Sufi berpotensi sebagai sumber pembelajaran Antropologi secara materi nilai budaya terdapat dalam mata pelajaran Antropologi kelas XI, Kompetensi Dasar 3.3 dan 4.3.
\end{abstract}

Kata kunci: Nilai Budaya; Sumber Pembelajaran Antropologi; Tari Sufi

\section{Sufi Dance: Study of Cultural Values and Their Potential As a Source of Anthropology Learning in MAN 1 Magetan}

\begin{abstract}
The MAN 1 Sufi Magetan dance performance can be explored as a source of Anthropology learning for students, students can learn cultural values in the MAN 1 Magetan Sufi dance performance. This research was conducted at MAN 1 Magetan within a period of 6 months. Using a qualitative approach, with informants as follows: Sufi dancers, Kyai Budi, Extracurricular Trustees of Sufi dance, Sociology / Anthropology teachers. The informant was determined by Purposive Sampling technique. Data collection techniques using observation, interviews and documentation. The data obtained were validated by source triangulation and triangulation methods. Data analysis techniques in an interactive way and take place
\end{abstract}

DOI: $10.25273 /$ gulawentah.v4i2.5557

Copyright (C) 2019 Universitas PGRI Madiun

All rights reserved. 
continuously with the stages of reducing, presenting data and concluding all information correctly. The Sufi dance MAN 1 Magetan was used as an extracurricular activity and attracted students and the public. This dance has a movement procedure as taught by Kyai Budi, an Indonesian Sufi figure who introduced this dance in the Magetan region including MAN 1 Magetan. In a flexible presentation, the costume does not wear a black robe, which is released when it will dance, the color of the costume does not have to be black and white and white and can be patterned, batik pring sedapur for example. Also do not use quff as footwear but wear ordinary socks. Floor pattern does not follow a certain pattern but adjusts to the venue and the number of dancers. Sufi Dance MAN 1 Magetan contains cultural values, namely: philosophical values, aesthetic values, spiritual values, mental improvement values, loving values, brotherly values, hospitality values, healthy values, and economic values. Sufi dance has the potential as a source of learning Anthropology in terms of cultural values contained in the Anthropology class XI, Basic Competencies 3.3 and 4.3.

Keywords: Cultural Value; Anthropological Learning Resources; Sufi Dance.

\section{Pendahuluan}

Keragaman budaya (Cultural Diversity) tidak dapat dipungkiri keberadaannya di Indonesia. Budaya asli di Indonesia banyak bercampur dengan budaya asing. Apalagi didukung oleh faktor geografis, dimana Indonesia terletak di persimpangan lalu litas perdagangan dunia. Perkembangan dan penyebaran agama juga mempengaruhi dan mendukung perkembangan kebudayaan Indonesia sehingga Indonesia dapat dikatakan sebagai salah satu negara yang memiliki tingkat heterogenitas budaya yang tinggi (Iskandar, 2017; Sutardi, 2007; Wiranata, 2011). Kesenian merupakan salah satu penyangga kebudayaan yang bersifat kreatif dan berkembang menurut kondisi kebudayaan itu sendiri. Salah satu kesenian yang diminati masyarakat adalah seni tari. Tari dari luar yang diminati masyarakat contohnya adalah tari Sufi. Tari Sufi merupakan tarian berputar yang berasal dari negara Turki dengan pendirinya Jalaluddin Rumi. Tari Sufi ini juga mengandung nilai-nilai budaya yang luhur, yaitu tentang hubungan dengan Sang Pencipta (Habluminalloh) dan hubungan dengan manusia (Habluminnanas).

Permendikbud RI No. 22 tahun 2016 menyebutkan sasaran pembelajaran mencakup pengembangan ranah sikap, pengetahuan, dan keterampilan. Kurikulum 2013 juga menitikberatkan atau mengutamakan pembentukan sikap, keterampilan, dan pengetahuan secara utuh. Senada dengan hal tersebut mata pelajaran Antropologi, berperan untuk mengembangkan kompetensi peserta didik dalam menghargai dan bersikap toleran terhadap keberagaman budaya, religi/agama, tradisi dan bahasa sebagai anugerah dari Tuhan Yang Maha Esa.

Kesenian merupakan salah satu unsur kebudayaan yang bersifat universal. Indonesia memiliki keanekaragaman seni dan budaya. Salah satu wujud keanekaragaman seni adalah tarian Sema Jalaludin Rumi, kalau di Indonesia lebih dikenal dengan tari Sufi, karena dulu di Turki penari tarian ini adalah orang-orang Sufi. Dalam bahasa Arab Sema berarti mendengar atau jika di terapkan dalam definisi yang lebih luas, bergerak dalam suka cita-cita sambil mendengarkan nada-nada musik sambil berputar-putar sesuai dengan arah putaran alam semesta. Di Barat tarian ini lebih dikenal sebagai Whirling Dervishe, atau para darwis yang berputar putar devine dance (Ahmadi, 2017; Faiz, 2016; Putra, 2017).

Tarian Sufi (Whirling Dervishes) merupakan tarian religius dari Timur Tengah. Tarian ini merupakan inspirasi dari filsuf dan penyair Turki, Maulana Jalaludin Rumi, untuk mengenang sahabatnya yaitu Syamsuddin. Bagi al-Rumi, rasa cinta akan menimbulkan kerinduan, yang akhirnya akan melahirkan ekspresi luar biasa.Gerak berputar menjadi ciri Tari Sufi yang dikembangkan Rumi. Tari Sufi itu diciptakan sama sekali tidak mengacu pada 
bentuk keindahannya. Tujuan utamanya adalah mencari dimensi abstrak yang dapat mengantar seseorang pada wilayah ketuhanan (Sari, 2013). Dari uraian tersebut dapat disimpulkan bahwa tari Sufi yang disebut juga tari Sema adalah tarian berputar yang diciptakan oleh Jalaludin Rumi dan yang bertujuan untuk mendekat dan mempersembahkan rasa cinta seorang hamba pada Allah SWT.

Kostum yang dipakai penari Sufi (darwis) mulai dari topi (Sikke) berbentuk kerucut yang berasal dari Asia Tengah, sampai busana yang dipakai mengandung makna filosofis. Topi lakan melambangkan batu nisan, Jubah hitam yang dilepas ketika menari untuk memperlihatkan baju dalam berwarna putih melambangkan kebangkitan dan kebangkitan kembali setelah mati (Falah, 2015).

Tarian sufi mempunyai empat gerakan antara lain : Gerakan Tangan Mencengkram Bahu, gerakan ini mempunyai arti bahwa pertunjukkan akan dimulai dan menundukkan segala yang dimiliki di hadapan Allah. Karena segala sesuatu yang ada didunia pasti kembali kepada Allah. Kemudian gerakan tangan menghadap ke atas. Berdasarkan hasil wawancara yang dilakukan oleh peneliti gerakan tersebut berarti bahwa sang penari mendapat hidayah dari Allah dan tangan kiri menghadap kebawah berarti bahwa hidayah dari Allah harus disampaikan. Gerakan selanjutnya yakni gerakan kaki, kaki kiri sebagai tumpuan dalam menari kemudian penari melakukan gerakan berputar. Gerakan berputar ini mempunyai arti bahwa segala sesuatu yang ada di alam semesta ini berputar sesuai jalur edarnya dan menganggap seperti thawaf.

Menurut Koentjaraningrat (2009) suatu sistem nilai-nilai budaya terdiri atas konsepsi-konsepsi yang hidup dalam alam pikiran sebagian besar warga masyarakat mengenai hal-hal yang harus mereka anggap amat bernilai dalam hidup. Oleh karena itu, suatu sistem nilai budaya biasanya berfungsi sebagai pedoman tertinggi bagi perilaku manusia. Hasil penelitian ini bukanlah semata-mata nilai budaya tersebut, tetapi lebih menjurus kepada perwujudan nilai budaya yang tampak di masyarakat yang tergambar dalam tari.

Jamaris (1993) mengungkapkan bahwa nilai budaya dikelompokkan ke dalam lima pola hubungan, yaitu; (1) nilai budaya dalam hubungan manusia dengan Tuhan, (2) nilai budaya dalam hubungan manusia dengan alam, (3) nilai budaya dalam hubungan manusia dengan masyarakat, (4) nilai budaya dalam hubungan manusia dengan orang lain atau sesamanya, (5) nilai budaya dalam hubungan manusia dengan dirinya sendiri.

Sumber belajar adalah segala daya yang dapat dimanfaatkan oleh guru guna memberikan kemudahan bagi seseorang dalam belajarnya (Winataputra, Delfi, Pannen, \& Mustafa, 2014). Sumber belajar terdiri dari pesan, manusia, material (media software), peralatan (hardware), teknik (metode) dan lingkungan yang secara sendiri-sendiri maupun bersama-sama (kombinasi) untuk memfasilitasi kegiatan pembelajaran (Hidayat, 2011). Dalam konteks pembelajaran Ilmu-Ilmu Sosial materi Nilai Budaya terdapat dalam mata pelajaran Antropologi kelas XI pada Kompetensi Dasar Menemukan nilai-nilai kultural yang disepakati bersama oleh masyarakat Indonesia dalam rangka membangun sikap toleran, empati, dan saling menghargai sehingga tercipta masyarakat multi etnik Indonesia yang rukun, aman, dan damai, 4.3. Melakukan refleksi/diskusi untuk menarik kesimpulan tentang nilai-nilai kultural nasional Indonesia (misalnya: gotong royong, tolong menolong, kekeluargaan, kemanusiaan, tenggang rasa) dalam ra ngka membangun sikap toleran, empati, dan saling menghargai sehingga tercipta masyarakat multi etnik Indonesia yang rukun, aman, dan damai, yang tertuang dalam materi : Konsep tentang nilai-nilai Kultural (cultural values), pewarisan nilai-nilai kultural atau proses sosialisasi dan enkulturasi. Sumber belajar memiliki berbagai manfaat penting dalam kegiatan pembelajaran. Sumber belajar tidak hanya bermanfaat untuk menyalurkan pesan, tetapi juga strategi, metode, dan tekniknya sehingga kegiatan belajar agar menjadi lebih efektif dan efisien. Menurut (Hidayat, 2011), berdasar tipe atau asal-usulnya sumber belajar dibagi menjadi: 1) sumber belajar yang dirancang (learning resources by design), yaitu sumber belajar yang sengaja dibuat untuk tujuan instruksional. 2) Sumber belajar yang sudah tersedia, sehingga tinggal dimanfaatkan (Learning Resources by Utilization). 
Adanya kondisi riil bahwa proses pembelajaran di MAN 1 Magetan yang belum memanfaatkan potensi yang ada di sekelilingnya sebagai sumber pembelajaran dan fakta adanya tari Sufi di MAN 1 Magetan yang terkandung keunikan dan kekuatan simbol-simbolnya, serta didukung adanya kompetensi dasar tentang nilai budaya pada pada mata pelajaran Antropologi, maka perlu diadakan penelitian ini.Di MAN 1 Magetan kesenian tari Sufi ini diminati peserta didik maupun masyarakat. Tari Sufi MAN 1 Magetan sering diundang untuk tampil dalam perhelatan di kantor Kementerian Agama Kabupaten Magetan, juga pada event-even yang diadakan Pemerintah Daerah Kabupaten Magetan. Namun demikian, makna yang terkandung dalam tarian ini banyak orang yang tidak tahu, di MAN 1 Magetan sekalipun, yang sudah berkembang tarian ini, tidak semua peserta didiknya mengetahui maknanya. Yang dinikmati penonton hanya keunikan berputarnya. Fakta pada peserta didik MAN 1 Magetan, penguasaan nilai budaya dalam arti penerapan nilainya belum menggembirakan. Guru-guru pengajar mata pelajaran Ilmu Sosial juga jarang menggunakan potensi yang ada di lingkungan sekitarnya sebagai sumber pembelajaran. Proses pembelajaran juga masih sering dilaksanakan dalam kelas, sehingga peserta didik menjadi jenuh.

\section{Metode Penelitian}

Penelitian ini dilakukan di MAN 1 Magetan selama 6 bulan. Pendekatan yang digunakan yakni kualitatif deskriptif karena sesuai dengan sifat, ciri dan tujuan yang ingin dicapai dalam penelitian ini bukan untuk menguji hipotesis tetapi berupaya untuk mengungkap fakta bahwa nilai-nilai budaya pada tari sufi bisa dijadikan sebagai sumber pembelajaran mata pelajaran Antropologi di tingkat SMA/MA.

Informan yang dipilih dalam penelitian ini adalah; penari Sufi, Kyai Budi Hardjono tokoh Sufi dari Semarang yang memperkenalkan dan mengajarkan tarian Sufi pertama di wilayah Magetan (termasuk di MAN 1 Magetan), pembina ekstra tari Sufi MAN 1 Magetan, guru-guru mata pelajaran Antropologi/Sosiologi di MAN 1 Magetan. Penentuan informan memakai teknik Purposive Sampling. Menurut Nawawi (1993) dalam penelitian yang bersifat kualitatif maka sampel penelitian yang diambil disesuaikan dengan tujuannya, sesuai dengan kriteria-kriteria tertentu yang ditetapkan berdasarkan tujuan penelitian. Sampel ini disebut Purposive Sampling atau sampling yang disengaja.

Sumber data yang digunakan adalah: 1) sumber data primer yang merupakan data yang diperoleh secara langsung dari informan, berupa keterangan atau fakta atau aktivitas yang terkait dengan tari Sufi MAN 1 Magetan. Selain juga kajian nilai budaya tentang Tari Sufi dan potensinya sebagai sumber pembelajaran Antropologi; 2) Sumber data sekunder data yang terkumpul yang menunjang data primer. Dalam hal ini adalah Profil MAN 1 Magetan, Dokumen Kurikulum 2013, absensi peserta Ekstra Kurikuler Tari Sufi, catatan dari peserta didik yang ikut Tari Sufi, serta foto-foto kegiatan. Teknik pengumpulan data yang digunakan yaitu wawancara mendalam, observasi dan dokumentasi. Adapun instrumen utama penelitian ini adalah peneliti sendiri dengan menggunakan logika dan berpikir analitik sehingga mampu menyimpulkan. Sedangkan instrumen bantu yaitu alat tulis, kamera dan rekam audio visual.

Prosedur penelitian dilakukan secara bertahap, yakni dari perencanaan dan perancangan, menentukan fokus penelitian, waktu penelitian, pengumpulan data, analisis dan penyajian hasil penelitian. Data yang diperoleh divaliditasi dengan tehnik triangulasi sumber dan triangulasi metode dimana informasi dikumpulkan dari sumber yang berbeda dan informan yang berbeda. Triangulasi ini dilakukan untuk memperkuat data, dimana dilakukan secara terus menerus sampai peneliti puas dengan datanya, dan yakin datanya valid.

Analisis data dalam penelitian ini dilakukan secara interaktif dan berlangsung secara terus menerus. Menurut Miles dan Huberman (2002), penelitian kualitatif dilakukan secara interaktif dan berlangsung secara terus menerus melalui tahapan mereduksi data, menyajikan data dan menarik kesimpulan. Reduksi data artinya kegiatan pemilihan data. Penyajian data 
adalah penyajian informasi yang tersusun. Kesimpulan data (verifikasi) berarti tafsiran atau interpretasi terhadap data yang telah disajikan.

\section{Hasil dan Pembahasan}

Tari Sufi MAN 1 Magetan didirikan tahun 2015 pada waktu dikepalai oleh Drs. Ary Siswanto, M.Si. dan waktu itu dijadikan sebagai kegiatan ekstrakurikuler. Semula Tari ini merupakan kegiatan santri-santri di Pondok Pesantren Sabilil Muttaqien (PSM) Takeran. Dan santri-santri pondok ini sebagian besar adalah siswa dari MAN 1 Magetan. Perlu diketahui bahwa antara Pondok PSM dengan MAN 1 Magetan terdapat ikatan historis yang sangat kuat karena Madrasah Mualimin PSM dulu, yang menjadi cikal bakal berdirinya MAN 1 Magetan. Berdiri pada tahun 1967, dan merupakan Madrasah Aliyah Negeri tertua di Indonesia. Sehingga dalam segala kegiatan dari dahulu sampai sekarang, kedua lembaga ini tidak dapat dipisahkan.

Tari Sufi di Pondok PSM diusung ke MAN 1 Magetan berawal pada waktu perbincangan Drs Ary Siswanto, M.Si. dengan pengasuh pondok yaitu Alm. Ustadz Ubaidilah Ridho, dimana pada waktu itu Bapak Ary Siswanto mengungkapkan kegiatannya untuk memberikan kegiatan ekstra yang bermanfaat untuk siswa. Curhatan itu disambut positif oleh Bpk Ridho dengan menawarkan untuk mengusung Tari Sufi ke MAN 1 Magetan. Sebelumnya tari Sufi ini sudah menjadi kegiatan santri di Pondok PSM, dikenalkan dan diajarkan oleh Kyai Budi Hardjono dari Semarang, seorang tokoh Sufi di Indonesia. (penuturan Bpk Sujud, Pembina Tari Sufi MAN 1 Magetan, wawancara pada September 2018).

Akhirnya dengan pembina Bpk Sujud (guru MAN 1 Magetan) tarian ini diberikan tempat, sarana prasarana dan waktu latihan rutin. Banyak siswa MAN 1 Magetan yang juga mukim di pondok sudah mahir menarikan tari Sufi ini. Merekalah yang mengajarkan tarian ini ke siswa yang lain di MAN 1 Magetan. Kyai Budi Hardjono, sering juga berkunjung ke madrasah untuk memantau dan memberikan motivasi kepada penarinya. Ketika beliau diundang mengisi pengajian di sekitar wilayah Magetan pasti penari Sufi MAN 1 Magetan ikut ditampilkan. Demikian juga apabila ada undangan menari di luar Magetan, banyak penari Sufi MAN 1 Magetan yang dikutkan. Jadilah tarian Sufi ini dikenal dan berkembang di wilayah Kabupaten Magetan. Apalagi Kepala MAN 1 Magetan yang sekarang, Drs Basuki Rachmat, M.Pd juga memberikan fasilitas dan kesempatan tarian ini tampil di even-even di luar, seperti ikut festival tari di Solo, tampil di acara perguruan tinggi wilayah Madiun, belum lagi yang acara-acara di dinas kabupaten maupun Kemenag. Pementasan yang berlangsung baru-baru ini adalah pada acara HARLAH Muslimat NU di Gelora Bung Karno, Jakarta, tanggal 27 Januari 2019 dan di Masjid Akbar, Surabaya dalam acara pelantikan Gubernur Jawa Timur terpilih, Khofifah Indarparawansa (14 Pebruari 2019).

Masyarakat sekitar sangat merespon positif keberadaan tarian ini, terbukti ketika masyarakat sekitar mengadakan hajatan pernikahan ataupun peringatan hari besar keagamaan di desa-desa, tari Sufi MAN 1 Magetan sering diundang untuk tampil. Dalam perhelatan di kantor Kementerian Agama Kabupaten Magetan-pun juga sering ditampilkan, juga pada event-event yang diadakan Pemerintah Daerah Kabupaten Magetan. Sambutan pejabat dan penonton yang hadirpun sangat antusias.

Berdasarkan hasil wawancara dengan Devi Rofiatus Sholikah, tata cara tari Sufi di MAN 1 Magetan yang diajarkan Kyai Budi adalah: 1) Diawali dengan berwudhu sebelum menari yakni berwudhu seperti saat akan salat. Wudhu ini untuk menyucikan diri dari hadats kecil. Seorang penari Sufi harus suci dari hadats besar maupun hadats kecil. 2) Melakukan shalat sunah syukur wudhu/sujud syukur. Shalat sunah syukur wudhu dilakukan untuk menunjukkan rasa syukur kepada Allah SWT atas nikmat yang diberikan. Yang sering dilakukan penari di MAN 1 Magetan adalah sujud syukur karena keterbatasan waktu dan tempat yang biasanya kalau akan pentas waktu yang ada terbatas juga tempatnya tidak memungkinkan. 3) Membaca Al-Fatihah (tawasul) yang ditujukan kepada kepada Nabi Muhammad SAW dan Syeikh Jalaludin Rumi. 4) Berdiri tegak dengan dengan tangan menyilang di dada dan mengatur nafas sambil berdzikir dalam hati. Dzikir yang dibaca adalah "Allahu, Allahu, Allahu..." atau 
"Hu". 5) Kemudian tubuh berputar berlawanan arah jarum jam. Secara perlahan-lahan, lalu tangan diturunkan secara perlahan, sampai di depan perut posisi jari tangan membentuk simbol "Love". Kemudian secara perlahan diangkat sampai dada hingga akhirnya tangan membentang. 6) Telapak tangan sebelah kanan menghadap ke atas, sedang telapak tangan kiri menghadap ke bawah. 7) Pandangan mata tertuju pada jari jempol sebelah kiri dan konsentrasi penuh, terus berputar serta berdzikir. 8) Ketika hampir selesei, posisi kedua tangan, seperti awal, yaitu menyilang di dada dan ketika selesei membungkuk seperti posisi rukuk untuk memberikan penghormatan dan sebagai tanda bahwa tarian sudah selesai (Hakim \& Ribha, 2019; Opsantini, 2014).

Bentuk penyajian merupakan wujud keseluruhan dari suatu penampilan yang didalamnya terdapat aspek-aspek yang ditata sedemikian rupa sehingga memunculkan keindahan. Aspek-aspek tersebut merupakan satu kesatuan yang tidak dapat dipisahkan dan mendukung suatu pertunjukan. Tari Sufi MAN 1 Magetan mempunyai unsur penyajian yang terdiri dari gerak, iringan, tata rias, busana, pola lantai dan panggung pertunjukan. Menurut (Falah, 2015; Putra, 2017) gerakan inti tari sufi adalah berputar, berputar ke arah kiri sebagaimana putaran tawaf di Ka'bah. Adapun urutan tarian Sufi pada saat pertunjukan adalah pertama, penari berjalan menuju panggung dengan meletakkan telapak tangan di dada dengan posisi tangan kanan di atas tangan kiri dibawah. Gerakan kedua, menundukkan badan dengan posisi rukuk, kedua tangan masih didada. Kemudian dengan lantunan sholawat berbunyi tanpa iringan musik, penari berputar perlahan ke arah kiri, dengan perlahan melepas tangan yang masih di dada, sampai di depan perut membentuk simbol "Love". Ketika musik masuk, dengan perlahan penari sedikit merentangkan tangan dengan posisi tangan kanan membentuk siku sejajar kepala dan telapak tangan menghadap atas, posisi tangan kiri sejajar dengan telinga dan posisi telapak tangan menghadap kebawah. Gerakan ketiga, penari mulai menari dari putaran lambat ke putaran yang cepat, semakin cepat putarannya kedua tangan direntangkan dengan posisi tangan kanan sejajar dengan kepala dan telapak tangan kanan menghadap keatas, lalu posisi tangan kiri sejajar dengan bahu dengan telapak tangan mengadap kebawah. Gerakan akhir, gerakan terakhir saat musik mulai lambat, penari berputar perlahan, tangan yang tadinya direntangkan kemudian perlahan disilangkan kembali ke dada seperti posisi awal dan membungkuk posisi rukuk untuk memberi penghormatan. Penari satu persatu meninggalkan panggung.

Tata rias pada tari sufi yaitu tidak menggunakan tata rias, maksudnya para penari tidak merias wajahnya. Karena semua mencerminkan fitroh (kesucian), tidak menonjolkan riasan wajah. Tetapi menonjolkan busana yang dipakai sebagai kostum sekaligus properti menari.

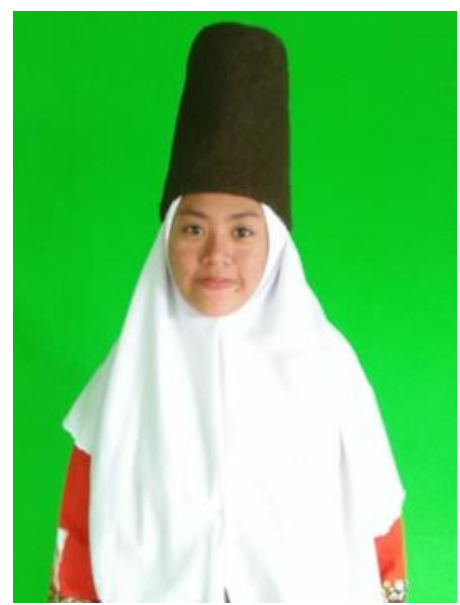

Gambar 1. Tata rias: Polos (Sumber: Ninik Wijayanti, Pebruari 2019) 
Busana yang dipakai dalam tari sufi, terdiri dari:

1. Topi Mawlawi (Sikke) yaitu topi panjang dan berwarna coklat ini melambangkan dan berbentuk batu nisan ala Turki yang menyimbolkan kematian;

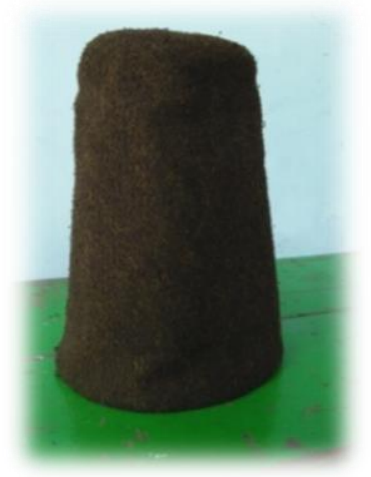

Gambar 2. Topi Sikke (Sumber: Ninik Wijayanti, Pebruari 2019)

2. Tennur yang terdiri dari: a) jubah hitam (hirqa) yang melambangkan ego dan dilepas ketika akan menari, (di MAN 1 Magetan hirqa ini tidak ada). b) Baju luar lengan panjang, yaitu semacam jaket yang talinya diikat dipinggang atau rok yang lebar dan melingkar; c) Baju dalam lengan pendek, yaitu semacam baju koko/kaos lengan pendek yang dipakai untuk bagian dalam.d) Jubah panjang dengan bawahan lebar melingkar yang akan digunakan untuk berputar. e) Celana panjang (untuk dalaman) f) Ikat pinggang (Stagen/Kendhit), berbahan dasar kain dan berwarna hitam, cara pemakaian dililitkan di pinggang setelah menggunakan baju dalam dan jubah panjang;

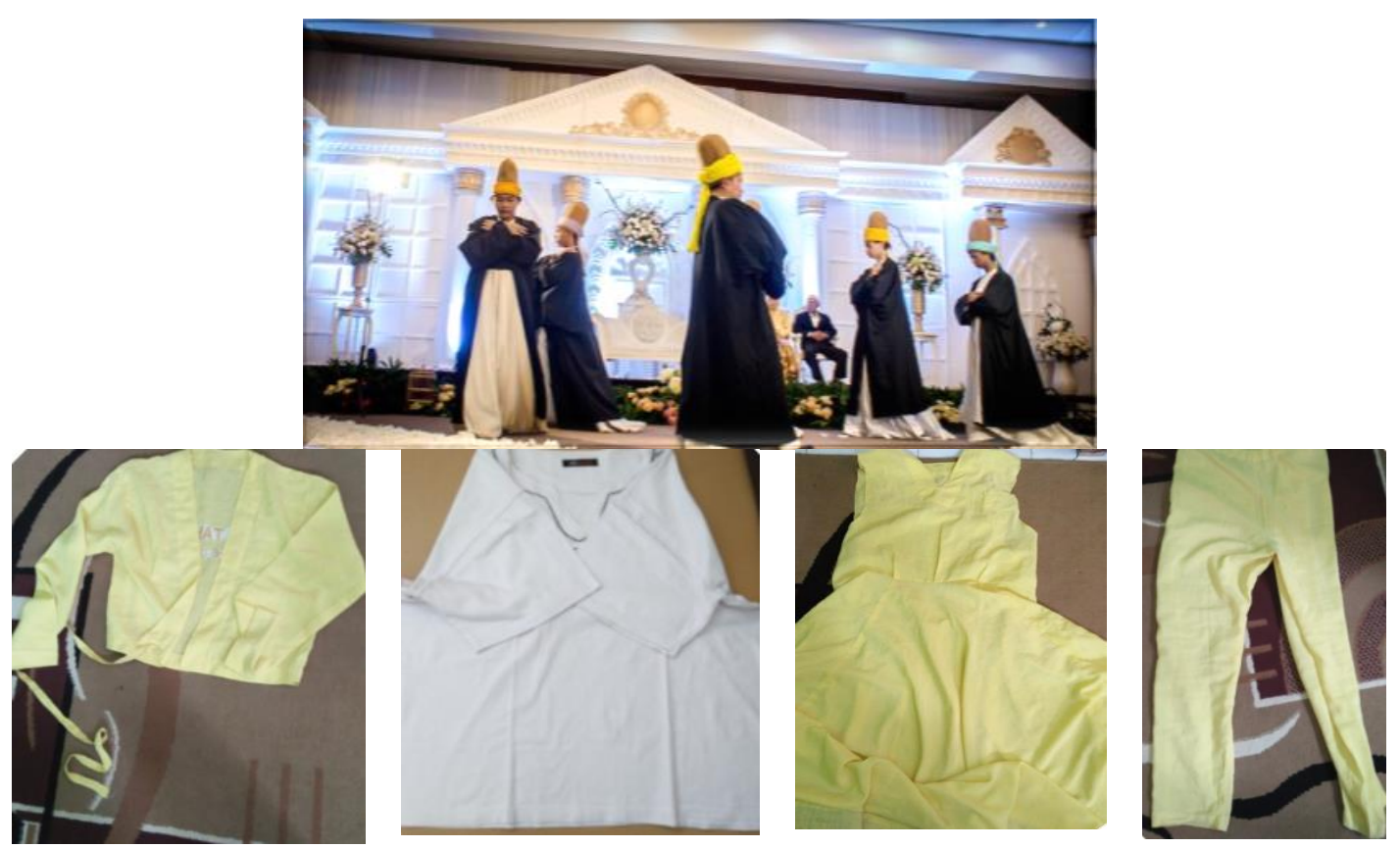

Gambar 3. Busana Tari Sufi (Sumber: Ninik wijayanti, Pebruari 2019)

3. Kaos Kaki (Quff)

Quff adalah kaos kaki yang terbuat dari kulit ini digunakan sebagai alas tumpuan saat berputar dan sebagai pengaman kaki agar tidak lecet atau luka, serta sebagai pelancar dalam berputar. Penari Sufi di MAN 1 Magetan tidak memakai Quff seperti penari asli dari Turki, tetapi memakai kaos kaki biasa. 


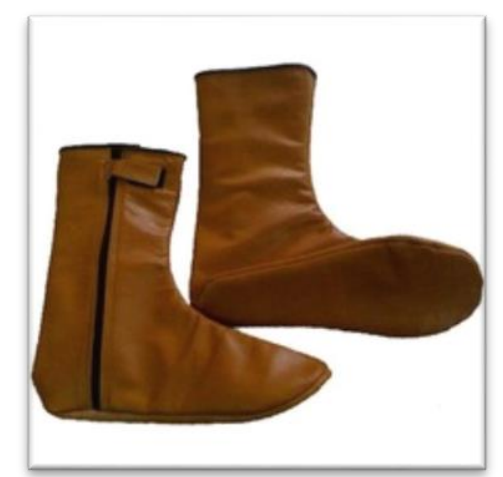

Gambar 4. Quff (Kaos kaki)

Untuk tata busana tidak harus berwarna hitam dan putih. Bisa dengan warna lain dengan petimbangan keindahan. Seperti yang disampaikan Kyai Abah Budi Hardjono, "Warna busana tidak harus hitam dan putih, boleh kuning, merah, hijau atau lainnya". Lebih lanjut beliau mengatakan bahwa busana tari Sufi tidak harus polos, apabila dibuat dari kain batik daerah setempat malah bagus, sekaligus untuk lebih mengenalkan potensi daerahnya" (Wawancara Juli 2018).

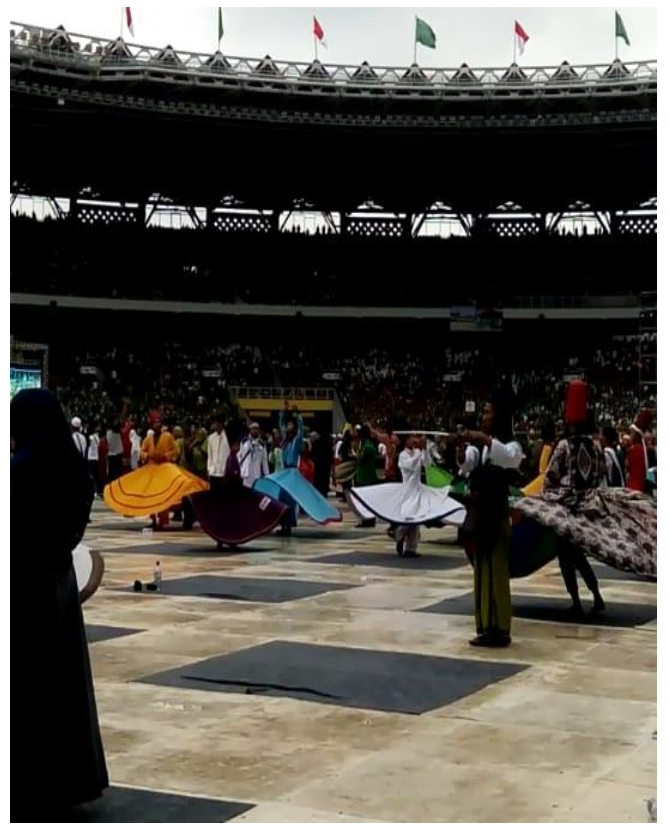

Gambar 5. Pertunjukan tari Sufi di GBK, Jakarta dengan berbagai corak busana tari sufi

Instrumen musik dalam pertunjukan tari sufi bisa apa saja, dipadukan dengan musik tradisional daerah setempat juga bisa. Seperti yang dikatakan Abah Budi Hardjono, "Tari Sufi bisa diiringi dengan musik apa saja, musik tradional setempat juga boleh, suara gemericik air juga bisa. Bahkan dulu Rumi ketika menari, musik pengiringnya adalah suara yang dikeluarkan oleh pandai besi”. (Wawancara Juli 2018).

Di MAN 1 Magetan sendiri, musik pengiring tari Sufi adalah hadrah habsyi dengan minimal 12 pemain yang memainkan alat musik 8 terbang/rebana, 1 bas, 2 keprak/marawis, dan 1 dumbuk atau darbuka. Syair yang dipakai adalah syair sholawat. 


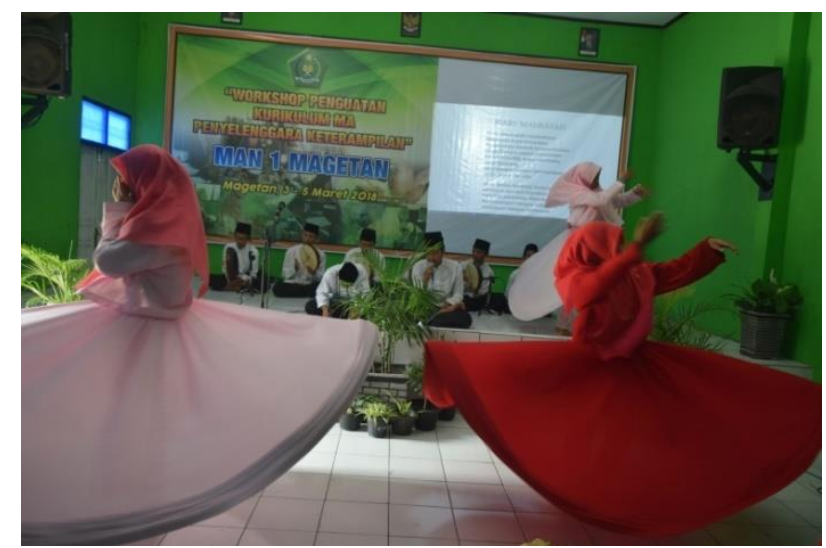

Gambar 6. Hadrah habsyi, musik pengiring tari Sufi MAN 1 Magetan

(Sumber : Ninik Wijayanti, 2018)

Pola Lantai pertunjukkan tari sufi MAN 1 Magetan tidak memiliki pola tertentu tetapi menyesuaikan tempat pertunjukan dan jumlah penari. Sedangkan tempat pertunjukan yang digunakan tari sufi ini pada dasarnya membutuhkan arena yang luas agar memudahkan penari dalam berputar, sehingga rok/tennur bisa berkembang meliuk-liuk dengan indah. Tempat pertunjukan tari sufi dapat ditampilkan di tempat terbuka ataupun tertutup. Tari Sufi Man 1 Magetan biasa tampil dimana saja, di panggung, halaman masjid, halaman rumah, lapangan, gedung pertemuan, bahkan pernah juga di jalan raya. Pada waktu itu mengikuti pawai Tujuh Belas Agustus dan tampil di sepanjang jalan, dan salah satu penari menari diatas mobil terbuka yang sudah disiapkan meja untuk menari. Hebatnya, penarinya tidak jatuh.

Gerakan dalam tarian sufi mengandung nilai-nilai filosofi (Ahmadi, 2017; Falah, 2015; Manan, 2013), sebagai berikut:

1. Makna gerakan berputar berlawanan arah dengan jarum jam.

Dalam tarian sufi gerakan ini memiliki arti bahwa pada dasarnya segala hal berputar. Putaran juga terjadi pada kehidupan manusia. Manusia berawal dari tidak ada, kemudian menjadi ada, dan akhirnya kembali tiada. Perputaran tersebut tidak ada satu pun yang melenceng dari porosnya. Gerak berputar tersebut juga mempunyai makna filosofis sebagaimana putaran orang yang sedang bertawaf di Ka'bah. Dengan tawaf, bentuk penyatuan diri kepada Sang Pencipta, seorang muslim berarti mengikuti irama alam semesta. Gerakan berputar mendorong manusia untuk tunduk dan merendahkan diri. Seluruh alam semesta bertawaf menyembah Allah dan bergerak bersamanya. Alam semesta pun tunduk kepada Nya.

2. Makna gerakan tangan.

Urutan gerak dalam tarian sufi mengandung nilai-nilai Islami, diantaranya: a) Pada awal menari, penari meletakkan kedua telapak tangan di dada dengan posisi tangan kanan diatas tangan kiri yang memiliki nilai pengendalian segala sesuatu, sebagaimana hidup dimulai kelahiran, sesuatu yang ada pasti ada awalnya. Dengan keimanan kita yakin bahwa semuanya berawal dari Allah. Maka dengan takdir kita mengembalikan kepada segala aktivitas kita adalah karena Allah. Gerakan awal ini berarti penyerahan totalitas pada yang Maha Awal bahwa karena Nya kita ada dan karenanya kita melakukan perjalanan hidup; b) Pada saat menari telapak tangan kanan menghadap ke atas ini melambangkan setiap saat kita menerima rahmat atau karunia dari Allah; c) Tangan kiri menghadap kebawah bahwa mengingatkan kita seyogyanya manusia senantiasa memberikan cinta kasihnya kepada seluruh makhluk Allah yang ada di alam semesta ini.

3. Makna Gerakan kaki

Kaki kanan yang digunakan untuk melakukan putaran memiliki makna bahwa seseorang akan melangkah ke arah yang lebih baik. Kaki kanan pun ketika melakukan pergerakan 
menyimbolkan bahwa ia menginjak-injak segala sifat keduniawian dan memilih untuk melangkah kearah yang benar yaitu, seusuai putaran yang sebenarnya. Kaki kiri sebagai tumpuan pun memiliki makna bahwa bagaimanapun seseorang bergerak asalkan memiliki tumpuan yang jelas maka orang tersebut tidak akan terperosok ke dalam jurang kemaksiatan

Tari Sufi MAN 1 Magetan yang merupakan kegiatan ektrakurikuler mempunyai fungsi sebagai sarana hiburan, media pergaulan, media pendidikan, dan sebagai media katarsis (pembersihan jiwa). Sebagai sarana hiburan khususnya ini bagi penarinya, dimana para penari Sufi ini pertama ikut menari adalah sukarela, dorongan hatinya sendiri yang penasaran pada tarian ini dan ingin bisa. Tidak ada paksaan dari pihak manapun, orang tua, teman atau pihak madrasah sendiri. Arahnya lebih ke kepuasan diri sendiri saja bagi penarinya, karena bisa menarikan tari Sufi ini (Faiz, 2016; Hakim \& Ribha, 2019). Meskipun demikian tarian ini juga ditampilkan dengan tujuan menghibur penonton, selain juga ingin memperkenalkan tari Sufi ini kepada masyarakat sebagai salah satu wujud tarian Islam.

Sebagai media pergaulan. Tarian ini bersifat kolektif, dilakukan bersama-sama dengan penari lain dalam penyajian dan penggarapannya juga melibatkan orang lain, baik dalam penyedian busana, musik pengiring maupun saat pementasan. Ketika diundang menari di acaraacara di luar wilayah, memungkinkan penari Sufi MAN 1 Magetan bertemu dengan penari lain dari luar daerah. Di situlah mereka mempunyai kesempatan bergaul lebih luas dan bisa menambah pengalaman. Sebagai media pendidikan. Tari Sufi mengandung makna filosofi yang mendalam dan nilai-nilai budaya yang sangat bermanfaat untuk dipahami dan diimplementasikan (Manan, 2013; Putra, 2017; Sari, 2013). Diharapkan nilai-nilai ini dapat merubah dan membangun karakter yang lebih baik bagi penarinya, juga penonton yang menyaksikan.

Sebagai media katarsis atau pembersihan jiwa. Tari Sufi ini merupakan sarana dzikir untuk mendekatkan diri pada Allah SWT. Dengan sering dzikir dan bersholawat melalui menari ini diharapkan hati menjadi bersih, tidak hanya memikirkan urusan dunia saja. Seperti pernah disampikan salah satu penarinya, "Dengan berdzikir hati menjadi tenteram" (wawancara dengan Devi, salah satu penari Sufi). Ajaran dalam tari Sufi mempunyai dua pola hubungan, yaitu hubungan manusia dengan Allah SWT (Habluminallah) dan hubungan manusia dengan manusia (Habluminnas). Adapun nilai-nilai budaya yang ada pada Tari Sufi, antara lain : 1) Nilai Filosofi. Setiap gerak maupun busana yang dipakai penari sufi mempunyai makna filosofi yang mendalam; 2) Nilai Estetika. Tarian ini menonjolkan keindahan gerak dan busana tari Sufi yang bisa meliuk indah ketika digunakan menari. 3) Nilai Spiritual. Tari Sufi menjadi sarana untuk mendekatkan diri kepada Allah dengan cara berdzikir dan bersholawat. Dengan sering berdzikir sembari menari menambah keimanan (keyakinan) kepada Allah SWT dan nabi Muhammad SAW. Dengan sering mendekatkan diri kepada Allah melalui menari Sufi sambil bersholawat, hati menjadi tenang dan tenteram; 4) Nilai Perbaikan mental, sebagaimana mental seseorang yang meledak-ledak (gampang marah) maka akan lebih bisa mengontrolnya. Orang tersebut akan bisa sabar, karena dalam tarian Sufi juga dipahamkan yang namanya kesabaran dan keikhlasan, sehingga perlahan akan merubah perangai penarinya, yang dahulunya pemarah lambat laun menjadi baik; 5) Nilai cinta kasih. Inti ajaran tari Sufi adalah cinta, cinta kepada Allah SWT dan cinta kepada sesama makhluk. Dengan memiliki cinta kepada Allah SWT maka manusia akan "mabuk melayani". Melayani kepada sesama makhluk artinya berbuat kebaikan kepada sesamanya baik tumbuhan, hewan terlebih kepada manusia 6) Nilai persaudaran. Sesama penari Sufi MAN 1 Magetan sudah seperti saudara, tidak ada persaingan di antara sesama penari. Siapa saja yang ditunjuk menari, diterima saja. Tidak terpikir untuk harus selalu anak tertentu saja yang tampil; 7) Nilai silaturahmi. Dengan seringnya ikut menari di beberapa even akan memungkinkan silaturohmi dengan sesama penari Sufi dari wilayah lain. Yang belum kenal menjadi kenal, yang sudah kenal bisa semakin akrab, menjadi banyak mempunyai teman Bahkan antara sesama penari Sufi di nusantara ini mempunyai grup 
Whatshapp dimana mereka aktif berinteraksi. Jadi pergaulan mereka menjadi luas tidak hanya sesama penari Sufi di wilayah Magetan saja. 8) Nilai sehat. Tarian ini juga membiasakan hidup sehat, karena dengan berputar (bergerak) ini tubuh mengeluarkan keringat. Keringat ini bisa mengeluarkan racun-racun dalam tubuh sehingga badan menjadi sehat. 9) Nilai ekonomis. Tarian ini juga mempunyai nilai ekonomis karena setiap diundang menari sering penarinya diberikan uang transport. Kostum tari Sufi yang dipunyai MAN 1 Magetan juga sering disewa oleh penari dari luar madrasah dan dari ini akan mendapatkan biaya sewa.

Tari Sufi berpotensi untuk dijadikan sebagai sumber pembelajaran Antropologi SMA/MA karena materi nilai budaya terdapat dalam mata pelajaran antropologi kelas XI pada Kompetensi Dasar 3.3. Menemukan nilai-nilai kultural yang disepakati bersama oleh masyarakat Indonesia dalam rangka membangun sikap toleran, empati, dan saling menghargai sehingga tercipta masyarakat multi etnik Indonesia yang rukun, aman, dan damai, 4.3. Melakukan refleksi/diskusi untuk menarik kesimpulan tentang nilai-nilai kultural nasional Indonesia (misalnya: gotong royong, tolong menolong, kekeluargaan, kemanusiaan, tenggang rasa) dalam rangka membangun sikap toleran, empati, dan saling menghargai sehingga tercipta masyarakat multi etnik Indonesia yang rukun, aman, dan damai, yang tertuang dalam materi: Konsep tentang nilai-nilai kultural (cultural values), pewarisan nilai-nilai kultural atau proses sosialisasi dan enkulturasi. Selain itu juga mengandung makna filosofis dan nilai-nilai budaya yang mengutamakan pembentukan sikap, keterampilan, dan pengetahuan secara utuh. Hal ini sesuai dengan tujuan pembelajaran Antropologi secara umum yaitu: (1) pembangunan sikap mental toleran, saling menghargai, dan empati; (2) usaha untuk mempromosikan nilai-nilai kultural dan pembangunan karakter bangsa sehingga tercipta masyarakat multietnik Indonesia yang rukun, aman, dan damai.

\section{Simpulan}

Tari Sufi MAN 1 Magetan yang didirikan tahun 2015 sebagai kegiatan ekstrakurikuler diminati peserta didik juga masyarakat. Tari ini mempunyai tata cara gerakan seperti yang diajarkan Kyai Budi, tokoh Sufi Indonesia yang mengenalkan tarian ini di wilayah Magetan termasuk MAN 1 Magetan. Dalam penyajian bersifat luwes kostum tidak memakai jubah hitam yang dilepas waktu akan menari, warna kostum tidak harus hitam dan putih dan bisa bercorak, batik pring sedapur misalnya. Juga tidak memakai quff sebagai alas kaki tetapi memakai kaos kaki biasa. Pola lantai tidak mengikuti pola tertentu seperti pola garis atau pola melingkar tetapi menyesuaikan dengan tempat pertunjukan dan jumlah penarinya. Nilai budaya yang terkandung pada tari Sufi adalah: a) Nilai Filosofi. b) Nilai Estetika. c) Nilai Spiritual. d) Nilai Perbaikan mental e) Nilai cinta kasih, f) Nilai persaudaran, g) Nilai silaturahmi, h) Nilai sehat, i) Nilai Ekonomis. Kesimpulan 3) Tari Sufi berpotensi sebagai sumber pembelajaran Antropologi karena terdapat materi nilai budaya pada Antropologi kelas XI SMA/MA Kompetensi Dasar 3.3 dan Kompetensi Dasar 4.3. Selain itu juga mengandung makna filosofis dan nilai-nilai budaya yang mengutamakan pembentukan sikap, keterampilan, dan pengetahuan secara utuh. Hal tersebut sesuai dengan tujuan umum dari mata pelajaran Antropologi yaitu yaitu: 1. Pembangunan sikap mental toleran, saling menghargai, dan empati; 2. Usaha untuk mempromosikan nilai-nilai kultural dan pembangunan karakter bangsa sehingga tercipta masyarakat multietnik Indonesia yang rukun, aman, dan damai.

\section{Daftar Pustaka}

Ahmadi, R. (2017). Sufi Profetik: Studi Living Hadis Jamaah Tarekat Naqsyabandiyah Khalidiyah di Kabupaten Trenggalek. Jurnal Living Hadis, 2(2), 289-315.

Faiz, F. (2016). Sufisme-Persia Dan Pengaruhnya Terhadap Ekspresi Budaya Islam Nusantara. ESENSIA: Jurnal Ilmu-Ilmu Ushuluddin, 17(1), 1-15.

Falah, A. R. (2015). Makna tarian sufi Jalaluddin Rumi di Pondok Pesantren Roudlotun Ni'mah Kalicari Semarang. UIN Walisongo, 
Hakim, R., \& Ribha, M. R. (2019). Teologi dakwah inklusif dalam "Tari Sufi Nusantara”. UIN Walisongo,

Herdiansyah, H. (2010). Metodologi Penelitian Kualitatif untuk Ilmu-Ilmu Sosial. Jakarta: Humanika.

Hidayat, A. (2011). Budaya Banyumas Sebagai Sumber belajar IPS di SMP Kabupaten Banyumas. Paramita: Historical Studies Journal, 21(1).

Iskandar, J. (2017). Etnobiologi dan keragaman budaya di indonesia. Umbara: Indonesian Journal of Anthropology, 1(1).

Jamaris, E. (1993). Nilai budaya dalam beberapa karya sastra Nusantara: sastra daerah di Sumatra: Pusat Pembinaan dan Pengembangan Bahasa, Departemen Pendidikan dan Kebudayaan.

Koentjaraningrat, K. (2009). Ilmu Antropologi. Jakarta: RIneka Cipta.

Manan, A. (2013). Makna Simbolik Gerak Tari Rabbani Wahid. Jurnal Ilmiah Peuradeun, 1(1).

Miles, M. B., \& Huberman, A. M. (2002). The qualitative researcher's companion: California: Sage Publications.

Nawawi, H. (1993). Metode Penelitian Bidang Sosial. Yogyakarta: Gadjah Mada University Peress.

Opsantini, R. D. (2014). Nilai-Nilai Islami Dalam Pertunjukan Tari Sufi Pada Grup "Kesenian Sufi Multikultur" Kota Pekalongan. Jurnal Seni Tari, 3(1).

Putra, A. D. (2017). Estetika Sema Dalam Tarekat Sufi Naqsybandi Haqqani Jakarta Sebagai Media Penanaman Pendidikan Tauhid. Gondang: Jurnal Seni dan Budaya, 1(1), 26-39.

Sari, N. (2013). Keberadaan tari sema jalaluddin rumi pada kelompok Tari sufi Jepara Di Desa Kriyan, Kecamatan Kalinyamatan, Kabupaten Jepara, Jawa Tengah (Skripsi). Yogyakarta: Universitas Negeri Yogyakarta.

Sutardi, T. (2007). Antropologi: Mengungkap keragaman budaya: PT Grafindo Media Pratama.

Winataputra, U. S., Delfi, R., Pannen, P., \& Mustafa, D. (2014). Teori belajar dan pembelajaran.

Wiranata, I. G. A. (2011). Antropologi Budaya: Citra Aditya Bakti. 